\title{
GEOTOURISM VALORISATION OF SELECTED QUARRIES OF KŁODZKO REGION AND CIESZYN FOOTHILLS
}

\author{
Katarzyna Kasprowska-NowaK ๑ ${ }^{1}$, Aneta MareK ๑ ${ }^{2}$ \\ ${ }^{1}$ Institute of Physical Education, Tourism and Physiotherapy, Jan Długosz University, Częstochowa, Poland \\ ${ }^{2}$ Institute of Geography and Regional Development, University of Wrocław, Poland
}

Manuscript received: December 18, 2018

Revised version: January 26, 2019

\begin{abstract}
KasprowsKa-NowaK K., MareK A., 2019. Geotourism valorisation of selected quarries of Kłodzko Region and Cieszyn Foothills. Quaestiones Geographicae 38(1), Bogucki Wydawnictwo Naukowe, Poznań, pp. 41-51. 2 figs, 3 tables.

ABSTRACT: The article presents a geotourism valorisation of selected quarries located in different mountainous regions in southern Poland, diverse in geological and tectonic terms. The regions of Kłodzko (with quarries Kletno I, Krzyżnik, Sinica, Czarne Urwisko, Szczytna Zamek) and of Cieszyn Foothills (quarries Na Jasieniowej, Na Mołczynie, Grota na Rudowie, Nad Kalembianką, Ondraszkowa Dziura) were proposed as a case study. The survey describes the most exposed disused quarries of marble, gneiss, sandstone, teschenites and Cieszyn limestone of high natural and cultural significance. As a result of the geotourist valorisation, the analysed geological objects were given point score under various criteria (educational value, scientific value, visual value, location/accessibility value, cultural value, geo-infrastructural value and the value of legal protection). It was found that the discussed quarries reveal high natural and educational value, and they are very significant in education and promotion of geologically attractive areas.
\end{abstract}

KeY wORDS: Eastern and Central Sudetes, Outer Western Carpathians, quarries, valorisation criteria, geotourism

Corresponding author: Katarzyna Kasprowska-Nowak, k.kasprowska-nowak@ajd.czest.pl

\section{Introduction}

The main aim of the study is to develop a catalogue of information on the historical and the most interesting excavation sites of various raw rock material located in two picturesque mountainous areas of Poland, i.e. the Sudetes and the Carpathians (considered to be cross-border areas). The choice of these areas was dictated by personal attachment of the authors to the Kłodzko Region and Cieszyn Foothills, a variety of research conducted in these areas, and the need to perform geotourism valorisation of the selected quarries, which had not yet been done. Inactive quarries are of interest to researchers representing various scientific disciplines due to their geocomplex character understood as a system of closely interrelated environmental elements (including rocks, morphology, water, microclimate, vegetation etc.). The issues of quarries' functionality and their attractiveness have been frequently taken up in literature. The management of disused excavation sites and the possibilities of their adaptation, as well as revitalization processes have been dealt with, among others, by Malewski (1999), Sarosiek (1999), Krawczyk, Lorenc (2010), Baczyńska, Lorenc (2012), Jawecki (2012), Poros, Sobczyk (2013). In addition, in many publications, attention was given to the use of quarries for various purposes (e.g. Górna 
2006, Pietrzyk-Sokulska 2008, Skoczylas 2009, Nita 2012, 2014, Kasprowska-Nowak 2014, Ptak 2015, Marek, Wiśniewska 2017).

The quarries of the regions of Kłodzko and Cieszyn Foothills, selected for the study are the most exposed in the area and are distinguished by significant natural and cultural value (geological and historical heritage). These objects have an exceptional scientific and educational value, which requires a broader and comprehensive study by interdisciplinary researchers. The geotourist valorisation of selected objects will provide knowledge about their present condition and will allow their evaluation. It will also promote interest in geotourism in various regions of Poland. In addition, it will be an important contribution to the development of geotourism guides compatible with the tourist routes planned by the authors, taking into account the most interesting geological objects in the discussed regions.

\section{Characteristics of the study area}

The regions of Kłodzko and Cieszyn Foothills are located in southern Poland (Fig. 1) and are extremely diverse in terms of geology and tectonics. The Kłodzko region is a historic area located in the Lower Silesia province, in the Kłodzko district, on the border of two physico-geographical units: the Eastern and Central Sudetes. In the east and south-west, the area is surrounded by massifs made of metamorphic rocks forming the Orlica-Śnieżnik dome. It consists of rocks of gneiss series and schist series with insertions of old Palaeozoic quartzites, marbles, amphibolites, metarhyolites as well as granites and eclogites (Koszela 2014). The north-western part of the Kłodzko region is built of sandstone table hills of the Stołowe Mountains composed of formations of the Upper Cretaceous. The northern part of the discussed area is the Bardo structure, represented by sandstones, greywackes and siltstones with graptolite and silica schist intrusions. In the vicinity of the Bardo structure there are rocks of the Kłodzko Metamorphic structure, dominated by phyllites, amphibolites and crystalline limestones. The north-eastern part of the Kłodzko region is built of rocks of the Kłodzko-Złoty Stok granitoid massif, formed as a result of the rock masses lifting (igneous intrusion). The rocks of this unit are mainly represented by granodiorites, granites, tonalites, and quartz diorites. The central part of the Kłodzko region is the upper Nysa trench, whose longitudinal axis is marked by the Nysa Kłodzka River. The area is filled with sedimentary rocks of the Upper Cretaceous, mainly composed of sandstones, marls and conglomerates (Milewicz, Wójcik 1973).

The area of Cieszyn Foothills (fragment of the mesoregion of Silesian Foothills), and especially its western part, covers the areas included in the former Duchy of Cieszyn and currently Cieszyn Silesia. In administrative terms, it is located in the southern part of the Silesian Province, in the Cieszyn District. An important role in its geological structure is played by the Cieszyńska nappe (tectonic unit of the Outer Flysch Carpathians). It is built of a series of schists, so-called (lower and upper) Cieszyn schists, separated by layers of Cieszyn limestones (classified as the highest Jurassic and the lowest Cretaceous) with

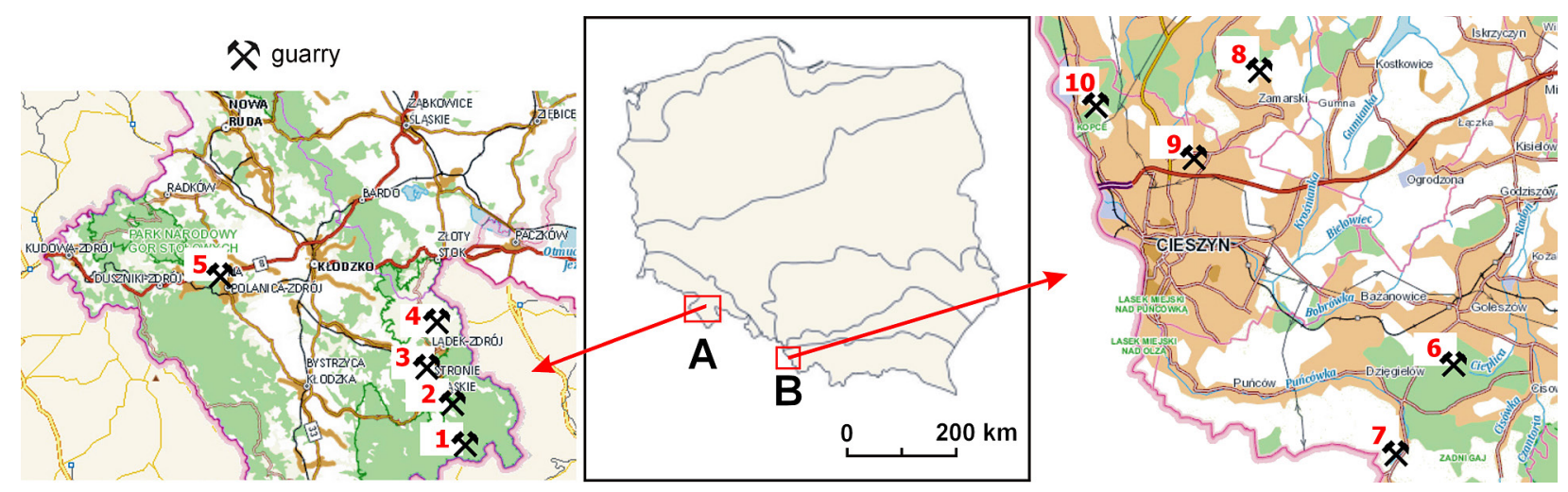

Fig. 1. Location of the selected quarries in the Kłodzko Region (A) and Cieszyn Foothills (B).

1 - Kletno, 2 - Krzyżnik, 3 - Sinica, 4 - Czarne Urwisko, 5 - Szczytna Zamek, 6 - Na Jesieniowej,

7 - Na Mołczynie, 8 - Grota na Rudowie, 9 - Nad Kalembianką, 10 - Ondraszkowa Dziura. 
teschenite intrusions (early Cretaceous igneous rocks associated with the so-called Cieszyn magmatic province, which stretches from Hraníce in Moravia to Bielsko-Biała; Buzek 1932, Pesztat 1967, Ciborowski, Gruszczyński 2001, Grabowski et al. 2004, Włodyka, Karwowski 2004). The overlayer consists of formations from younger geological periods represented, among others, by gravels, tills, sands and loess (Burtanówna et al. 1937).

\section{Methods}

The study is based primarily on long-term field research, during which direct observation and inventory survey of the quarries was carried out, as well as descriptive documentation (taking into account the valuation criterion of the characterized objects) and photographic documentation was performed. Within sites of former rock extraction (Ondraszkowa Dziura excavation) several samples were taken for petrographic tests using scanning electron microscope (SEM) with energy-dispersive $\mathrm{X}$-ray spectroscopy (EDS) analytical attachment and scanning electron microscopy in order to determine the rocks building the object (rock type and chemical composition).

Desktop methods involving the analysis and interpretation of cartographic and archival materials as well as literature survey, analysed mainly in terms of tourist attractiveness, also proved to be indispensable. For the purposes of this article, the authors developed their own criteria for geotourist valorisation, taking into account a range of values (educational, scientific, visual, location/accessibility, cultural, infrastructural and legal protection) in order to compare the attractiveness of the objects (quarries) in different mountainous areas of Poland and to facilitate the choice of places attractive to explore for potential tourists. The criteria for geotourism valorisation of the discussed objects are presented on a scale from 1 to 3 (Table 1 ).

Table 1. Criteria for geotourism valorisation and scoring categories.

\begin{tabular}{|c|c|}
\hline I - Educational value & $\begin{array}{l}\text { Point } \\
\text { score }\end{array}$ \\
\hline high (object with a rare type of geological and geomorphological structure) & 3 \\
\hline medium (object with a frequent type of geological and geomorphological structure) & 2 \\
\hline low (object with a common type of geological and geomorphological structure or without such) & 1 \\
\hline \multicolumn{2}{|l|}{ II - Scientific value } \\
\hline high (found in national scientific literature) & 3 \\
\hline medium (found in regional scientific or popular science literature) & 2 \\
\hline low or none & 1 \\
\hline \multicolumn{2}{|l|}{ III - Visual value (accessibility of geological structure for direct observation) } \\
\hline high (geological and geomorphological structures are very visible) & 3 \\
\hline $\begin{array}{l}\text { medium (geological and geomorphological structures are partially visible, possibility of clearing the rock } \\
\text { walls) }\end{array}$ & 2 \\
\hline $\begin{array}{l}\text { low (geological and geomorphological structures are visible only in places - obscured by vegetation or not } \\
\text { visible at all) }\end{array}$ & 1 \\
\hline \multicolumn{2}{|l|}{ IV - Location value in terms of accessibility } \\
\hline easily accessible, marked & 3 \\
\hline accessible, unmarked & 2 \\
\hline poorly accessible, unmarked & 1 \\
\hline \multicolumn{2}{|l|}{ V - Cultural value } \\
\hline very close connection with the history of the region and mining & 3 \\
\hline medium connection with the history of the region and mining & 2 \\
\hline little or no connection with the history of the region and mining & 1 \\
\hline \multicolumn{2}{|l|}{ VI - Infrastructural value (geotourism development) } \\
\hline high (geotourism route, accompanying facilities) & 3 \\
\hline medium (information board on site) & 2 \\
\hline low or none & 1 \\
\hline \multicolumn{2}{|l|}{ VII - Legal protection value } \\
\hline high (national rank) & 3 \\
\hline medium (regional rank) & 2 \\
\hline low (local rank) or none & 1 \\
\hline
\end{tabular}




\section{General characteristics of selected quarries}

\section{Quarries of the Kłodzko region}

\section{Quarry Kletno I}

The inactive marble quarry in Kletno, referred to as Kletno I (Fig. 2B, Table 2), is located in the south-eastern part of the Kłodzko region, in the northern part of the Śnieżnik Massif, in the upper part of the Kleśnica valley, in the village of Kletno (50¹4'15.86" N, 1650'52.22" E). More precisely, it is located near the access road and the tourist trail (yellow colour) leading towards Jaskinia Niedźwiedzia (the Bear Cave). Its convenient location and visual prominence attracts frequent tourists. The outcrop of dolomite marbles forms a rectangle, $300 \mathrm{~m}$ long and $170 \mathrm{~m}$ wide, which is surrounded by mica schist (Ciężkowski 1989, Cacoń et al. 1993). Almost the entire outcrop area is occupied by Kletno I slope quarry. Lenses of carbonate rocks, about $40 \mathrm{~m}$ thick and $100 \mathrm{~m}$ long (Koszela 1997) are exposed there. In the quarry there are small caves and shelters between several and a dozen metres long. At the foot of the excavation walls there is rock debris resulting from erosive activity of water and weathering. The bottom of the excavation is partially filled with water. The first information on the occurrence of marbles in Kletno dates back to around 1865 (Ciężkowski 1986, Ciężkowski et al.1996). Exploitation activity was carried out in the 1930s. After World War II, quarries resumed operation in 1958. The raw material was exploited until 1993. The object was closed due to its detrimental impact on Jaskinia Niedźwiedzia discovered in 1966. The quarry represents the slope and pit type. In the vicinity of the quarry there are numerous protected plant species, including orchids Dactylorhiza fuchsii subsp. Fuchsie and Orchis militaris as well as rare animals' species, in this part of the Sudetes, such as the mountain goat Rupicapra Rupicapra.

\section{Quarry Krzyżnik}

The quarry (of slope type) is located in the Eastern Sudetes, on the southern slope of Mt Krzyżnik (about $701 \mathrm{~m}$; 50¹7'0.57" N, 1651'29.86" E), part of the Śnieżnik Massif. The excavation is located approx. $200 \mathrm{~m}$ below the peak. An unmarked and overgrown path leads to the excavation site. In the lower part of the quarry there are visible white crystalline limestones, which gradually turn upwards into mica schist (Fig. 2A). The thickest (several metres) layer of crystalline limestones, occurs in the form of a recumbent fold, whose amplitude is $20 \mathrm{~m}$, with a radius of $7 \mathrm{~m}$. In the upper part of the outcrop there are thinner layers and lenses of marbles in the form of recumbent and overturned folds. Minerals are represented by garnets and calcites. In numerous places there are holes remaining after mining blasting works (Table 2).

\section{Quarry on Mt. Siniak slope}

The described quarry (slope type) is located on the north-western slope of Mt. Siniak $658 \mathrm{~m}$ ), $\left(50^{\circ} 19^{\prime} 26.08^{\prime \prime} \mathrm{N}, 16^{\circ} 50^{\prime} 1.83^{\prime \prime} \mathrm{E}\right)$. It is located approx. $150 \mathrm{~m}$ from the red trail going from LacdekZdrój towards Czarna Góra (1205 m). A forest path leaves the trail and leads towards the excavation site. At the intersection of these routes there are small wooden amenities (for recreation purposes) and a signpost to the excavation site. The geological structure of the peak includes mica schist, gneisses, amphibolites, quartzites and marbles (Figs 2C, D, Table 2). The quarry reveals quartzites among which there are minerals such as quartz, muscovite, tourmaline, garnet. Its geotourist attractiveness is enriched by the overturned fold flank visible in the side wall of the excavation, in its eastern part; an interesting outcrop of black graphite quartzites occurring in the north-western side of the summit, as well as by the occurrence of small folds with visible quartz veins. The quarry is included in the didactic path Trail of rocks of the Stronska Formation. The interior of the quarry is overgrown with shrubs. The upper edge of the quarry is an interesting scenic point offering a panorama of Massif of Śnieżnik, Krowiarka and Złote Mountains.

\section{Quarry Czarne Urwisko}

Quarry Czarne Urwisko (slope type) is located in the Eastern Sudetes, in the Złote Mountains, on Mt. Strzybnik slope (about $720 \mathrm{~m}$ ), within the administrative boundaries of the town of LacdekZdrój (50²1'25.99" N, 1653'38.98" E). The quarry reveals a basalt volcanic pipe formation with a distinct vertical separation (Jaworska 1986). These rocks, forming four-, five- and six-angle columns, were created due to tensions in the cooling lava 


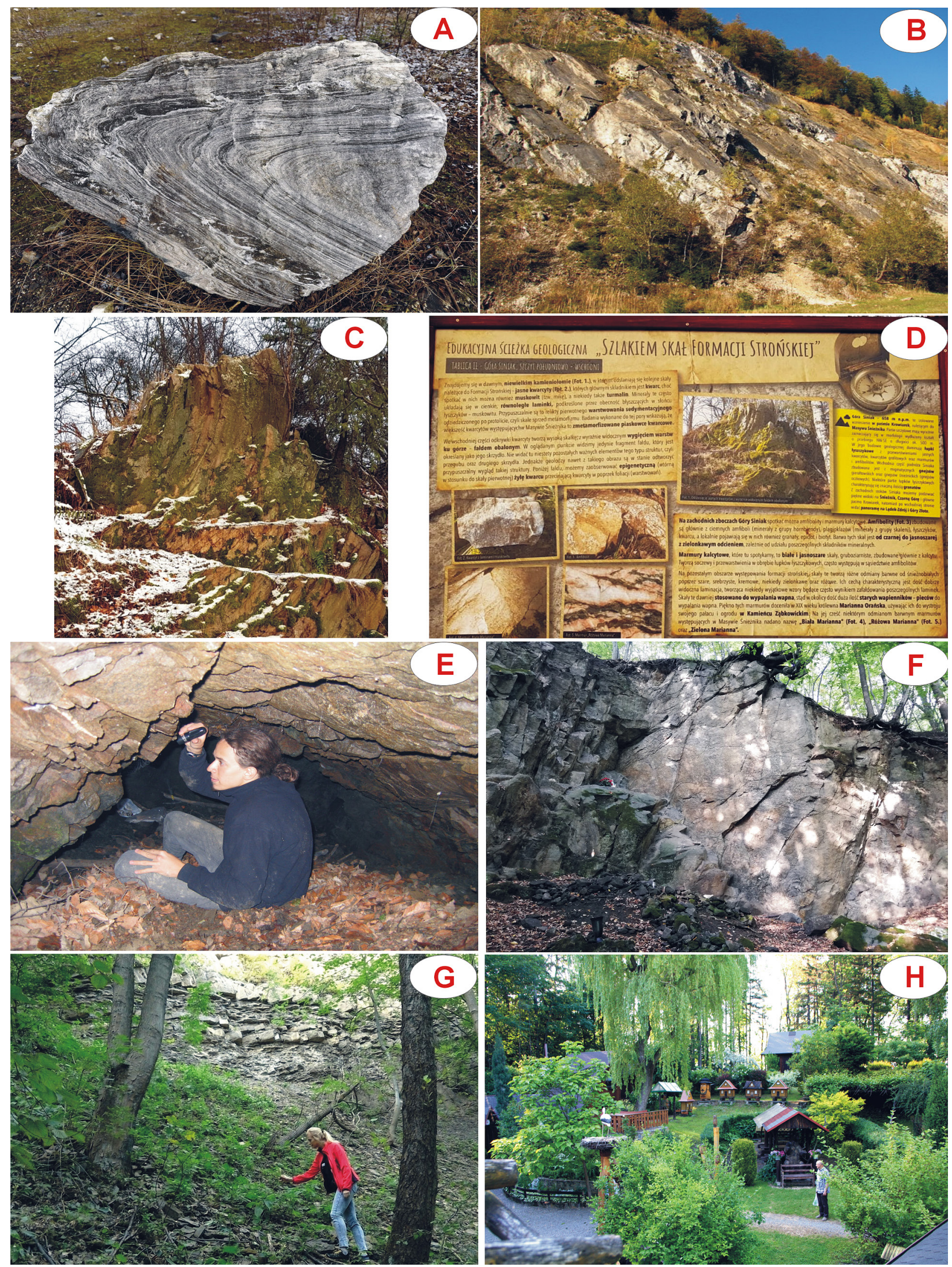

Fig. 2. Examples of geological structures and tourist infrastructure in the quarries.

A - Krzyżnik, B - Kletno I; C, D - Sinica, E - Ondraszkowa Dziura (adit of teschenites), F - Grota na Rudowie, G - Na Jasieniowej, H - Na Mołczynie. 


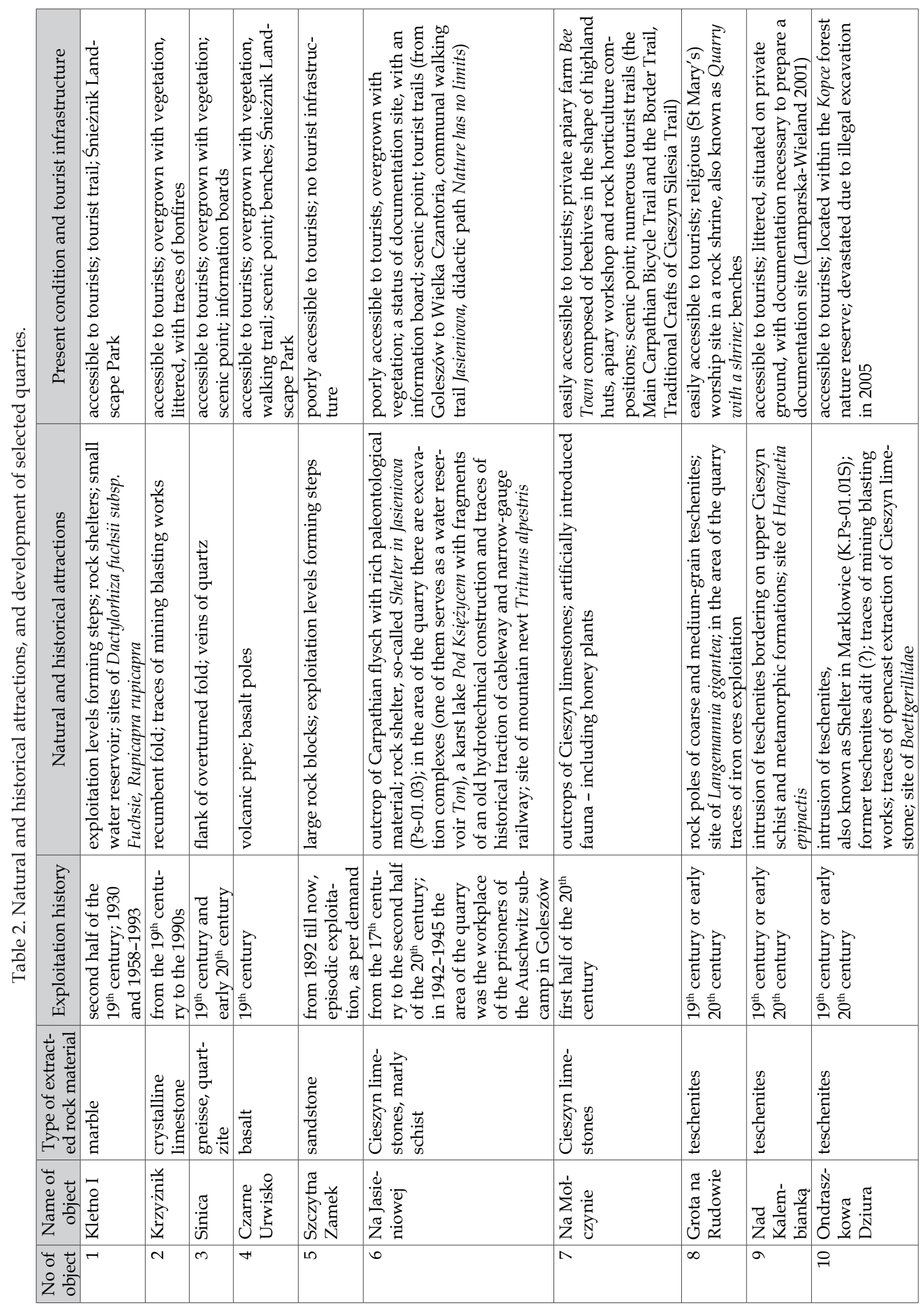


(Table 2). The resulting cracks perpendicular to the cooling surface are called a thermal joint. The specimens include olivine and pyroxene crystals or volcanic glass. In the $19^{\text {th }}$ century, a slope quarry operated here. It uncovered a wall of approximately 60 meters of height. The object has been entered into the Catalogue of geotourism objects in Poland (Słomka et al. 2006). A marked path leads to the upper edge of the quarry, with a panorama of the Śnieżnik Massif. In the past, on the edge of the former excavation site there was an observation platform on which from the mid- $19^{\text {th }}$ century to 1945 there was an arbour. Access to the lower parts of the object is hindered by a mixed forest.

\section{Quarry Szczytna Zamek}

The discussed quarry is located in the southern part of the Stołowe Mountains, on the slopes of Wysoki Kamien, above the Bystrzyca Dusznicka valley and on the Szczytna - Polanica Zdrój route, above the railway embankment $\left(50^{\circ} 23^{\prime} 59.1^{\prime \prime} \mathrm{N}\right.$, $\left.16^{\circ} 29^{\prime} 15.1^{\prime \prime} \mathrm{E}\right)$. The excavation can be accessed by a forest road, not marked, which diverts from an asphalt road, directly behind the bridge over the Bystrzyca Dusznicka. The described object belongs to the Radków Sandstone Mine, though the exploitation has not been carried out for several years.

In the quarry, the Upper Cretaceous sandstones of the Sudetian depression are exposed. In addition, there are sandstone layers, whose thickness ranges from several to a dozen or so meters, with a distinct joint separateness. The sandstone is white, yellow and cream-coloured, fine-grained, with a random structure. It has silica cementation. Rock mining in the area of Szczytna functioned already in the $19^{\text {th }}$ century. The quarry is of a slope type. Millstones were made in the local sandstone quarry. Sandstone from Szczytna Zamek was used for decorative elements in numerous buildings of Warszawa, Kraków, Poznań, as well as Berlin and Koszyce (Walendowski 2009).

\section{Quarries of Cieszyn Foothills}

\section{Quarry Na Jasieniowej}

The quarry is located in the complex of excavations located in the area of Jasieniowa Góra in Goleszów, also known as Goleszowska Górka (about $520 \mathrm{~m} ; 4^{\circ} 43^{\prime} 22.546^{\prime \prime} \mathrm{N}, 18^{\circ} 44^{\prime} 1.099^{\prime \prime} \mathrm{E}$ ). It is located on a karst lake called Pod Księżycem. The easiest way to reach it is along a forest road from the forester's lodge in Cisownica (KasprowskaNowak 2017a). The Na Jasieniowej quarry has an attractive outcrop of the Carpathian flysch (Fig. $2 \mathrm{G}$, Table 2), which is covered by nature conservation as Jasieniowa documentation site. It consists of series of different rocks - mainly light grey or grey-brown Cieszyn limestones with dendrites, interlayered with grey and green marly schist with a rich paleontological material (represented e.g. by ammonoidea, crinoidea and brachiopoda). The quarry is an excellent scenic point, offering views in the direction of the Silesian Beskid and Ustron ranges. In addition, there is a small rock shelter marked as Shelter in Jasieniowa (code: Ps-01.03 in the Cave Objects Database of the Polish Flysch Carpathians). The history of the quarry goes back to the 17th century, and should be associated with limestone calcination in lime kilns that were located on the slopes of Jasieniowa Góra. Its rapid development falls on the first half of the $20^{\text {th }}$ century and is related to increased demand for lime and the production of cement in the nearby Goleszów Cement Plant (it operated from 1898 to 1991). In the years 1942-1945, the cement plant was a branch of the Auschwitz concentration camp, in which, as well as in nearby quarries, the prisoners worked (Stanieczek 2015). The cement produced in it was of the highest quality - of the Portland type (before the founding of the cement plant there was a slate-stone burner there). Until the early 1950s, the output from the quarry was transported to the cement plant by means of a wooden narrow-gauge railway. After World War II, above the quarry, there was a cargo railway line, closed in 1984.

\section{Quarry Na Mołczynie}

The discussed quarry (associated with the exploitation of Cieszyn limestones for the needs of the local construction industry) is located in Dzięgielów (Goleszów commune) on the wooded hill of Mołczyn (about $440 \mathrm{~m}$; 49² $42^{\prime} 27.08^{\prime \prime} \mathrm{N}$, $\left.18^{\circ} 42^{\prime} 32.22^{\prime \prime} \mathrm{E}\right)$. More precisely, it is located opposite the Cieszyn limestone mine in Leszna Gorna (the only active one in Cieszyn Silesia), near the Poland-Czech Republic border crossing. Near the quarry there are marked cycling trails (the Main Carpathian Bicycle Trail and the Border Trail). The area of the quarry is about 16 acres and is 
surrounded by mixed forest and a hay meadow. Its uniqueness lies in the fact that since 1970 it has been adapted for the needs of an apiary composed of beehives in the shape of highland huts (Fig. 2H, Table 2), known in the region as the Bee Town (Kasprowska-Nowak 2017b). In its western wall of several metres of height, outcrops of Cieszyn limestone can be observed. Loose rock blocks found at the bottom of the excavation have been arranged into circles by the quarry owners. Along with other rocks, transported from the quarry in Leszna Górna, they create a variety of garden compositions and are elements of foundations, thus diversifying the landscape of the bee farm, where you can relax and taste local bee products. The Na Mołczynie quarry space perfectly harmonizes with the surrounding landscape of the Silesian Beskid. In addition, it can be considered an important symbol of the regional heritage associated not only with apiculture, but also with the history of the local mining industry and folk art.

\section{Quarry Grota na Rudowie}

The quarry (also known as the quarry with a shrine) is located on Kamienna Street in Zamarski (Hażlach commune) near Cieszyn (around 310 $\mathrm{m} ; 49^{\circ} 46^{\prime} 53.1^{\prime \prime} \mathrm{N}, 18^{\circ} 38^{\prime} 46.4^{\prime \prime} \mathrm{E}$ ), in the bottom of the Piotrówka valley, where iron ores (spherosiderites) were extracted. It is the site of the former extraction of coarse and medium-grained teschenites, for local needs (in road construction and as a component of mortar). Teschenites occur here in the form of stone pillars (height over $10 \mathrm{~m}$ ) leaning towards the east (Fig. 2F, Table 2). Occasionally they are accompanied by pyroclastic rocks in the form of fine layers of tuffs (Kasprowska-Nowak 2014). Its bottom is covered with teschenites waste (ideal as a mineral fertilizer for growing plants) and large rock blocks partially arranged in the shape of a cross, because it serves as a chapel for services. The interior of the quarry and rock shelves are filled with small religious items (figures), wooden benches and partly with litter. The exploitation of teschenites in the discussed quarry as well as in other quarries (described below) took place at the turn of the $19^{\text {th }}$ and $20^{\text {th }}$ centuries. The characterized rock raw materials were used for the needs of local construction and road building. Today they have no economic significance.

\section{Quarry Nad Kalembianką}

The quarry is located in Cieszyn - Boguszowice on Majowa St., in the left, steep slope of the Kalembianka stream (about 290 m; 4946'11.8" N, $18^{\circ} 37^{\prime} 27.2^{\prime \prime} \mathrm{E}$ ). The quarry reveals one of the largest intrusions of teschenite rocks in Cieszyn Foothills. It has a shape of an amphitheatre $(25 \times 25 \mathrm{~m})$ with rock walls reaching up to $17 \mathrm{~m}$ of height. In its lower part there are dark finegrained, sometimes porphyry, teschenites, which contact upper Cieszyn slates of a bright colour. In the contact zones, layers of dark contact hornstone and rust-coloured banded hornstone are exposed. The interior of the quarry is covered with large rock blocks and teschenites waste. The described quarry is on the list of potential geological objects in the Cieszyn region which meet the criteria to be covered by a form of protection as documentation sites (Lamparska-Wieland 2001, Table 2).

\section{Excavation site Ondraszkowa Dziura}

This object (of a rock shelter type) is located in the northern district of Cieszyn-Marklowice, in the left slope of a deep ravine in the Kopce nature reserve (about $282 \mathrm{~m} ; 4^{\circ} 46^{\prime} 44.1^{\prime \prime} \mathrm{N}, 18^{\circ} 36^{\prime} 23.6^{\prime \prime} \mathrm{E}$ ). It is known in the region as the Ondraszkowa dziura (the name comes from a legend associated with a highland robber's den) or Shelter in Marklowice (code: K.Ps-01.01S in the Cave Objects Database of the Polish Flysch Carpathians; Fig. 2E, Table 2). Its length is about $6 \mathrm{~m}$, and the width is about 2.5 $\mathrm{m}$. The opening has a circular shape and a northern exposure. The terrace in its vicinity is small (about $3 \times 4 \mathrm{~m}$ ) and covered with rock debris. It falls in the direction of the stream which flows 3 $\mathrm{m}$ below. The bottom of the shelter is partially littered and covered with leaves. It accumulates water in the form of a small lake, which freezes in winter and ice caps are formed on the walls. The ceiling is angular, damp and iron-containing. In its interior numerous spiders and slugs from the family Boettgerillidae can be observed. The object was mentioned by Czudek (1929), and then by Kowalski (1954), who described it as a several-metre-long tunnel, carved in the rock and partially buried. There are many indications that this is an underground excavation (adit) of teschenites extraction. In 2004 in the left rock face a round hole with a small diameter was identified, which most probably is a remnant of mining blasting works. 
Microscopic analyses indicate that the teschenites building the object are heavily weathered (biological weathering effect). In their chemical composition, analcime, hornblende, biotite, iron oxides, titanium, pyrite, chlorite and apatite were found. It is assumed that the area of the Ondraszkowa dziura is part of a larger mining area, where Cieszyn limestones were also extracted (Kasprowska 2010, Kasprowska-Nowak 2014).

\section{Results of geotourism valorisation}

The evaluation of the selected geotourist objects was based on seven criteria (Table 1). Each of them was assessed separately, and their rank and selection was determined by the subjective perception of the valorisation authors, resulting from many years of research in areas where the selected quarries are located. The results of geotourism valorisation of the selected quarries of the Kłodzko region and Cieszyn Foothills are presented in Table 3.

The valorisation reveals that among the analysed quarries, the cultural value dominates. This should be associated with the history of mining of local rock material (its development dates back to the second half of the $19^{\text {th }}$ century) for the needs of economy (industry, building, road construction, etc.), transport development (especially railway) and the events of World War II (forced-labour of prisoners of the Auschwitz subcamp in the Jasieniowa Gora quarries and in the cement plant in Goleszów).

The next places are taken by educational and scientific as well as visual values of the discussed excavations due to their natural attractions (occurrence of rare geological structures and unique rocks typical of a given region, e.g. teschenites or Cieszyn limestones) described in both geological scientific literature (including Catalogue of tourist objects in Poland) and popular science literature, especially regional (e.g. Geotourist assets of Kłodzko region). It is worth noting that a lower rank of visual value of the analysed quarries is determined by the considerable coverage of the excavations by vegetation, which requires partial removal from the most spectacular rock outcrops (this applies mainly to objects $\mathrm{Na}$ Jasieniowej, Nad Kalembianką, Krzyżnik and Sinica).

The poorest grades were given to location/ accessibility and infrastructure criteria due to difficult access, which results mainly from a lack of appropriate marking and information about the natural and cultural values of the discussed objects, as well as very poor, virtually negligible tourism infrastructure development. It appears that among all the quarries, the Na Mołczynie object is best developed, thanks to the efforts of its owners who had adapted the excavation site for the needs of a very original apiary (beehives in the shape of highlanders' huts), which attracts enthusiasts of apitourism from different parts of Europe.

In the overall assessment, the legal protection value of quarries was the worst. This probably results from the lack of knowledge about their natural and cultural values in local governments and among the local community, as well as from the lack of proper regulations regarding the ownership of the area where quarries are located. Quarries are widely regarded as places of former earning employment. After stopping the excavation, they usually do not constitute a greater value for local communities.

Table 3. Results of geotourism valorisation of selected quarries.

\begin{tabular}{|c|c|c|c|c|c|c|c|c|c|}
\hline \multirow{2}{*}{ No of object } & \multirow{2}{*}{ Name of object } & \multicolumn{7}{|c|}{ Category } & \multirow{2}{*}{ Point score } \\
\hline & & I & II & III & IV & $\mathrm{V}$ & VI & VII & \\
\hline 1 & Kletno I & 2 & 2 & 3 & 2 & 3 & 1 & 2 & 15 \\
\hline 2 & Krzyżnik & 3 & 3 & 3 & 2 & 3 & 1 & 1 & 16 \\
\hline 3 & Sinica & 2 & 1 & 2 & 3 & 1 & 3 & 1 & 13 \\
\hline 4 & Czarne Urwisko & 3 & 3 & 3 & 3 & 3 & 2 & 2 & 19 \\
\hline 5 & Szczytna Zamek & 2 & 1 & 1 & 2 & 1 & 1 & 1 & 9 \\
\hline 6 & Na Jasieniowej & 3 & 3 & 2 & 1 & 3 & 2 & 3 & 17 \\
\hline 7 & Na Mołczynie & 1 & 2 & 1 & 3 & 3 & 3 & 1 & 14 \\
\hline 8 & Grota na Rudowie & 3 & 3 & 3 & 2 & 3 & 1 & 1 & 16 \\
\hline 9 & Nad Kalembianką & 3 & 3 & 3 & 1 & 3 & 1 & 1 & 15 \\
\hline 10 & Ondraszkowa Dziura & 2 & 3 & 3 & 1 & 3 & 1 & 3 & 16 \\
\hline
\end{tabular}




\section{Conclusions}

Kłodzko region and Cieszyn Foothills are geologically interesting areas, due to the presence of numerous quarries (often forming complexes). As a result of the valorisation carried out, it was found that they are distinguished by special values, especially cultural ones (connected with the history of local mining, industry, transport and events of World War II) and educational and scientific ones (related mainly to the occurrence of rare geological structures and rocks typical of a given region, widely described in specialist literature). High educational values of quarries indicate that they have great geotourism potential. In the overall assessment, the legal protection value of quarries was the worst.

The most interesting quarries, despite the considerable exposure of rare geological structures (e.g. Krzyżnik, Czarne Urwisko, Na Jasieniowej, Nad Kalembianką), form of protection significant for geology (e.g. documentation site $\mathrm{Na}$ Jasieniowej), as well as availability of information about them, are poorly accessible and undeveloped for tourism. With the exception of quarries Sinica and Na Mołczynie, the infrastructural value of the remaining objects is very poor (no information boards, no wooden amenities for resting purposes etc.).

A significant part of the quarries (this concerns mainly Cieszyn Foothills) has a low location/accessibility value. These objects are mostly difficult to reach and unmarked. Currently, the state of the outcrops is reasonably good or rated as sufficient. Continuous ecological succession causes obscuring of the visual prominence of the quarries. Recommended measures include periodic removal of excess vegetation from rock walls, introduction of boards informing about the values of the discussed objects, litter removal, and locating and describing the observation sites of particular outcrops. For the Na Jasieniowej quarry, it is necessary to refer to technical relic (remains of narrow-gauge and cable railway) and to the forced-labour of the prisoners of the Auschwitz sub-camp, in the form of information boards.

Almost all the presented quarries are distinguished by special cultural values. They have a very strong link with the history of the discussed regions. Some of them (e.g. the Na Mołczynie quarry adapted for the needs of an apiary shaped like little highland huts) are important elements of regional heritage (crafts and folklore) and interesting objects for enthusiasts of apitourism.

The elaborated geotourism valorisation can become a useful and valuable tool for promoting geologically attractive areas in the discussed regions (especially in the form of guidebooks, brochures, geotourist routes, etc.). It can be particularly helpful for state institutions and communal authorities looking for new and interesting attractions (geotourist objects) that will attract tourists and activate the local community. Disused excavations can serve not only tourists and tour operators, but also students of local schools and natural sciences students to carry out various didactic activities, especially in the form of field classes.

According to the authors, it is necessary for communal authorities to cooperate with teams of interdisciplinary researchers and owners of the quarries in the field of their comprehensive description and subsequently providing access to tourists. Some of the discussed excavation sites (e.g. Nad Kalembianką and Czarne Urwisko) are eligible for nature conservation in the form of a documentation site.

\section{Acknowledgments}

The research project reported on the following paper was financed from Jan Długosz University grant DS/WP/6113/2018. We would like to thank the reviewers for their valuable comments and effort to improve the manuscript.

\section{Author's contribution}

Katarzyna Kasprowska-Nowak is responsible for the concept and writing the article, collecting, analysis and interpretation of data of Cieszyn Foothills, drawing Fig. 1,2 , construction of Table 2, critical review of the article and the final approval of the article for publication. Aneta Marek is responsible for collecting and interpretation data of Kłodzko region, construction of Table 1, 3 and preparation of conclusions resulting from the correlation of various data. The authors divide the contribution percentage as follows: Katarzyna Kasprowska-Nowak $50 \%$, Aneta Marek - 50\%.

\section{References}

Baczyńska E., Lorenc M.W., 2012. Problemowe kamieniołomy - proste rozwiązania. In: Zagożdżon P., Madziarz M. (eds.), Dzieje górnictwa - element europejskiego dziedzictwa kultury 4: 7-15. 
Burtanówna J., Konior K., Książkiewicz M., 1937. Mapa geologiczna Karpat Ślaskich. Wyd. Śląskie, Kraków.

Buzek K., 1932. Trzęsienia ziemi na Śląsku Cieszyńskim. Cieszynity. Rocznik Polskiego Towarzystwa Tatrzańskiego „Beskid Śląsi", Cieszyn: 4-13 .

Cacoń S., Ciężkowski W., Don J., Hutnik R., Rippel J., 1993. Ocena wpływu działalności kamieniołomu marmuru w Kletnie na Jaskinię Niedźwiedzią. Przegląd Geologiczny 10: 706-712.

Ciborowski T., Gruszczyński M., 2001. Carbonate and silicate coupled system recorded in the Lower Cieszyn Limestones, Western Carpathians. Biuletyn Państwowego Instytutu Geologicznego 396: 31-32.

Ciężkowski W., 1986. Historia górnictwa w dolinie Kleśnicy (Masyw Śnieżnika). Materiały Krajoznawcze Karkonosz. Wyd. SKPS, Wrocław: 5-13.

Ciężkowski W., 1989. Surowce mineralne doliny Kleśnicy oraz ich eksploatacja. In: A. Jahn, S. Kozłowski, T. Wiszniowska (eds.), Jaskinia Niedźwiedzia w Kletnie. Badania $i$ udostepnianie. Wydawnictwo Ossolineum, Wrocław: 137-146.

Ciężkowski W., Irmiński W., Kozłowski S., Mikulski S., Przeniosło S., Sylwestrzak H., 1996. Zmiany w litosferze wywołane eksploatacją surowców mineralnych. In: A. Jahn, S. Kozłowski, M. Pulina (eds.), Masyw Śnieżnika - zmia$n y$ w środowisku przyrodniczym. Wyd. PAE, Warszawa: 85-119.

Górna M., 2006. Kamieniołomy w paśmie Magurki Wilkowickiej obiektami geoturystycznymi. Geoturystyka 3: 57-62.

Grabowski J., Krzemiński L., Nescieruk P., Paszowski M., Szydło A., Pécskay Z., Wójtowicz A., 2004. Nowe dane o wieku skał cieszynitowych (Karpaty zewnętrzne, jednostka śląska) - rezultaty datowań metodą K-Ar. Przeglad Geologiczny 52 (1): 40-46.

Jawecki B., 2012. Kopalnie w krajobrazie powiatu strzelińskiego-wybrane przykłady zagospodarowania terenów poeksploatacyjnych. Architektura Krajobrazu 4: 24-34.

Jaworska I., 1986. Bazalty okolic Lądka-Zdroju. Pielgrzymy. Materiaty szkoleniowe do użytku wewnętrznego SKPS, AKT, Oddział Akademicki PTTK, Wrocław: 30-33.

Kasprowska K., 2010. Stanowisko A-1. Schronisko w Marklowicach. Materiaty 44. Sympozjum Speleologicznego, Kraków: 19-20.

Kasprowska-Nowak K., 2014. Znaczenie wybranych wyrobisk w krajobrazie i turystyce Pogórza Cieszyńskiego. Prace Komisji Krajobrazu Kulturowego 26: 175-187.

Kasprowska-Nowak K., 2017 a. Potencjał geoturystyczny w lasach Pogórza Cieszyńskiego. Studia i Materiaty CEPL w Rogowie 19, 52/3: 118-124.

Kasprowska-Nowak K., 2017 b. Sztuka pszczelarska w krajobrazie kamieniołomu na Śląsku Cieszyńskim. In: S. Bernat, M. Flaga (eds.), Inspiracje krajobrazowe. Wydawnictwo Wydziału Nauk o Ziemi i Gospdarki Przestrzennej UMCS, Lublin: 40-49.
Koszela S., 1997. Petrogeneza marmurów z południowo-wschodniej części metamorfiku Śnieżnika (Sudety). Geologica Sudetica 30: 59-115.

Koszela S., 2014. Budowa geologiczna Sudetów. In: A. Marek, I.J. Olszak (eds.), Sudety i Przedgórze Sudeckie. Środowisko, ludność, gospodarka. Wyd. Silesia, Wrocław: 53-68.

Kowalski K., 1954. Jaskinie Polski. Wydawnictwo PMA, Warszawa.

Krawczyk E., Lorenc M.W., 2010. Problem niewykorzystanego potencjału dawnych kamieniołomów na przykładzie Wieżycy i Chwałkowa (Dolny Śląsk). Geoturystyka 2: 27-34.

Lamparska-Wieland M., 2001. Projekt utworzenia stanowisk dokumentacyjnych przyrody nieożywionej w Cieszynie. MS, Urząd Miejski w Cieszynie.

Marek A., Wiśniewska A., 2017. Wykorzystanie geoturystyczne kamieniołomów Śnieżnickiego Parku Krajobrazowego. Studia i Materiaty CEPL w Rogowie 19, 52/3: 125-133.

Milewicz J., Wójcik L., 1973. Sudety. In: S. Sokołowski (ed.), Budowa geologiczna Polski. Stratygrafia. Wydawnictwa Geologiczne, Warszawa: 94-98.

Nita J., 2012. Quarries in landscape and geotourism. Geographia Polonica 85, 4: 5-12.

Nita J., 2014. Mining landscape as a type of cultural landscape. Prace Komisji Krajobrazu Kulturowego 23: 203-212.

Pesztat C., 1967. Rozwój litologiczny i warunki sedymentacji wapieni cieszyńskich. Prace Geologiczne Komisji Nauk Geologicznych 44: 1-116.

Pietrzyk-Sokulska E., 2008. Walory opuszczonych kamieniołomów na Wyżynie Krakowsko-Częstochowskiej. Surowce i Maszyny Budowlane 6: 42-45.

Poros M., Sobczyk W., 2013. Rewitalizacja terenu pogórniczego po kopalni surowców skalnych na przykładzie kamieniołomu Wietrznia w Kielcach. Rocznik Ochrona Środowiska 15: 2369-2380.

Ptak M., 2015. Dawne kamieniołomy dolnośląskie dzisiejszą atrakcją geoturystyczną. Bezpieczeństwo Pracy i Ochrona Środowiska w Górnictwie 9: 26-32. .

Skoczylas J., 2009. Adaptacja kamieniołomów wapieni dla potrzeb turystyki na przykładzie Malty i Egiptu. Problemy Ekologii Krajobrazu 24: 173-182.

Słomka T., Doktor M., Joniec A., Kicińska-Świderska A., 2006. Katalog obiektów geoturystycznych. Wydawnictwo AGH, Kraków.

Stanieczek P., 2015. Arbeitslager Golleshau - dzieje podobozu. Wydawnictwo Gmina Goleszów, Goleszów.

Walendowski H., 2009. Piaskowiec ze Szczytnej Śląskiej. Nowy Kamieniarz 7: 78.

Włodyka R., Karwowski Ł., 2004. The alkaline magmatism from the polish Western Carpathians. Mineralogical Society of Poland, Special Papers 4 (24): 23-31. 